three sections in the edited collection. The first section, Elections, Voting and Representation, examines the changing meanings of basic mechanisms of modern democracy. The second section, Democracy, Citizenship and Scale, is concerned with spaces where democracy is actualized at domestic/national levels and urban/regional/national levels, and with processes of international migration. A key part of this section is the concept of citizenship-formation, highlighting institutions, social relations and embodied practices, which creates and transforms citizenship in different contexts. The final section, Making Democratic Spaces, examines the what and the where of informal types of politics that are crucial to the further understanding of democracy and processes of democratization. The focus is on the public/private distinction and the interplays of the concept of public space, cultural practices and the role of social movements in a global context in developing a democratic public life. Overall, the collection seeks to broaden and deepen the scope of democracy to include the media, social movements, community mobilization, and interplays of associated culture. It also directs new questions to dominant theorizations of state-centred democratic polities to rethink elections and electoral systems, central-local state relations, and citizenship. The consideration of space, place and scale on existing conceptualizations of democracy generates exciting possibilities for normative questions about democracy, justice and legitimacy to be at the centre of critical human geography in its analysis of contemporary socio-economic metamorphoses.

Mary Walsh

Division of Business, Law \& Information Sciences, University of Canberra, Australia.

\author{
Hiding from Humanity: Disgust, Shame and the Law \\ Martha Nussbaum \\ Princeton University Press, Princeton, 2004, 432pp. \\ ISBN: 0691095264.
}

Contemporary Political Theory (2006) 5, 226-229. doi:10.1057/palgrave.cpt.9300226

Emotions, Nussbaum claims, are pervasive and it would be difficult to think of law without in some way including them. But they are also problematic. If they concern reasonable beliefs about goods which are important to have, don't people have different ones, and how then can we enforce them via the criminal law in a liberal society?

One way of dealing with that problem has been a form of utilitarianism where deterrence is the only variable, and the actual act, rather than internal 
emotions, intentionality, etc., is the focus. But, asks Nussbaum, how can you have such a system without doing damage to the way we ordinarily think of the operation of systems like the criminal law? Nussbaum wants to look at what part the emotions of disgust and shame should play in the institutions, especially the law, of a liberal society. She asks what sort of political and legal culture will be appropriate for enhancing respect for persons in a liberal regime; a society, that is, where we all recognize our vulnerable humanity out of a respect for the equality of each of us in that vulnerability.

Her book ultimately looks to the 'psychological foundations of liberalism, about the institutional and developmental conditions for the sustenance of a liberal respect for human equality' (p. 16). This is for her Millian in that it emphasizes liberty as well as equality and a space for creativity. Although her answer in substance is a Millian one, she aims to provide a better rationale for it than the famous harm principle.

She looks at disgust and shame and the part they should play in the law. Her approach is to look at the emotion and its cognitive content first and then see how that resonates with its use in law. Firstly, she considers disgust. Part of its 'thought content' seems to be the idea that we can be contaminated by certain core objects, which are a reminder of our mortality and animal vulnerability. It can extend to other objects by the idea of contagion. Disgusting things, once they have contact with something else, contaminate that object. Indignation and anger can be differentiated because they can rely on public argumentation. But to say something is disgusting is not give public arguments but show how they are connected to things we universally see as disgusting. It is therefore not a good criterion for public policy especially as disgust can be extended to exclude whole groups.

Thus, disgust is not a good basis for the criminalization of an act or as something to be used in mitigation or aggravation. Nussbaum carefully discusses cases in respect of 'the homosexual provocation defence', obscenity and cases where disgust is used to decide the severity of homicide. She shows how much of this is based on projection and group denigration. Her view is that in cases where the law appears to use disgust, one can better justify the law's intervention either by Millian arguments or arguments about respect or equality.

In looking at disgust in a variety of areas in the law and especially as an emotion that involves projection and group denigration, she insightfully shows how pornography statues based on disgust in fact project that disgust on to women in general. She also enables us to see the limits of disgust where it appears to be a legitimate category, as in nuisance law, where disgust can be the actual harm. Here, for example, a small amount of faeces in water even if in such quantity as not to contaminate the water could be a nuisance. But we must not include in this the idea of contamination of a lake by, for example, 
African-Americans swimming in it for that would be the unacceptable denigration of a particular group.

She then turns to shame and looks at what she calls 'primitive shame'. This is the shame of our imperfectability. This comes about in the child's anxiety at separation from the time when it was totally cared for and in control. This arouses both anger and love at the carer. Properly handled, the child will be able to accept its imperfectability and this will lead it on to creativeness. But if not, the child develops shame at its imperfectability and this shame leads to rage and impotence in any sort of relation. This, for Nussbaum, is closely connected to shame and humiliation. We rage because we do not live up to perfection. This then leads us to stigmatization, where we desperately seek to make ourselves normal by branding others as deviant.

One can see how this makes using shame in the law problematic. She argues against shaming punishments because they are connected with this 'primitive shame' and lead to stigmatization of minority groups in a bid to make ourselves normal. Thus, much of punishment by shame inevitably leads to branding of groups who are different as dangerous and as such engenders moral panics. She illustrates this, clearly and usefully, in a discussion of the role shame and disgust play in the moral panic around same sex marriages.

There are also implications for law when it comes to building a society where citizens are protected from shame. Firstly, such a society is one that implies a decent living standard for people to prevent the stigmatization and humiliation of poverty. This is an aspect of human dignity, which thus has welfare requirements. Secondly, minorities must be protected from stigma by guarding against discrimination and hate crimes. Finally we must work not to stigmatize the physically and cognitively disabled but rather try to mainstream them into society's institutions. Otherwise, we risk constructing a false view of ourselves as normal and them deviant and this connects back to primitive shame.

This is a fascinating book. What is special about it is the way it uses material from a variety of sources, especially psychoanalytic theory and literature, to enrich the position on the use of law. For Nussbaum, in a liberal society shame and disgust cannot normally be used to punish and she finishes the book with a discussion of whether all her points can be met by Mill's utilitarianism. She concludes that they cannot, though she agrees with what she sees as his substantive conclusions.

However, it does not seem clear to me that she is defending a strictly Millian position by a different route and at times the argument seems forced and irrelevant. But she defends clearly and with great skill her version of a liberal position. And notwithstanding its relation to Mill's position, her thesis is important and timely in its own right. Not only in its negative thesis, in its 
defence of law against those communitarians and others who would let shame and disgust play a role therein, but also for its positive thesis. This has two aspects. Firstly, she shows what the law should positively do to protect people from the negative effects of shame. Here, she is very suggestive when looking at ways of helping the physically and mentally disabled. Secondly, she points the way to the proper institutionalization of emotions in a civilized society. Communitarianism and contractarian liberalism leave deep issues about humans unresolved. The former think of people as either normal or not and the latter sees people as autonomous and independent. But we are all interrelated and vulnerable and indeed equal in our vulnerability. We must design institutions that realize that insight if we are to develop our society into a truly civilized one. What is important is that we are imperfect and fragile beings and it is in that that our beauty and humanity lie. As well as protecting ourselves from some emotions we need also to inculcate others such as love and compassion. This is an important and timely book, written with insight and passion.

Zenon Bañkowski University of Edinburgh, UK.

\section{The Postmodern Prince: Critical Theory, Left Strategy and the Making of a New Political Subject}

John Sanbonmatsu

Monthly Review Press, New York, 2004, 272pp.

ISBN: 1583670904.

Contemporary Political Theory (2006) 5, 229-231. doi:10.1057/palgrave.cpt.9300227

Taking inspiration from Antonio Gramsci's image of the communist party as a 'modern Prince', John Sanbonmatsu clarifies what he regards as some key intellectual preconditions for a contemporary radical left political strategy. The 'postmodern Prince' names the movement he encourages his audience presumably the American left — to understand as a long-overdue point of intellectual and organizational unity to an otherwise disparate collection of social movements, trade unions and radical oppositional groups. Too often in the past, he argues with great effect, these movements have succumbed to an 'expressivist' politics that prioritizes 'authentic self-expression' over discipline and long-term strategic unification. Thus, they have lost any sense of a common language of opposition and organizational coherence and, as a consequence, they have succumbed to the stronger will of neo-liberal capitalism and conservative reaction. 